\title{
Contents, Vol. 25, 1986
}

Founded 1897 as 'Monatsschrift fiir Psychiatric und Neurologic', continued 1957-1967 as 'Psychiatria et Neurologia' Founders C. Wernicke and Th. Ziehen. Successors: K. Bonhoeffer (1912-1938), J. Klaesi (1939-1967), F. Criminal (1953-1967)

\section{Editor-in-Chief}

Associate Editors C. Locb, Cienova H.-G. Mertens, Wurzburg U.K. Rinne, Turku H. vander Eecken, Ghent

Editorial Board

L. Barraquer Boardas, Barcelona

S. Feldman, Jerusalem

P. Hubcr, Bern

A. Kreindler, Buchares

H.J. Lehmann, Esse
C. Pallis, London

E. Satoyoshi, Toky

Advisory Board

Electromyography HP. Ludin, Bern

Neuroendocrinology

P.O. Lundberg, Uppsala

Cerebrospinal Fluid

F. Seitclberger, Vienna J. Ulrich, Basel F. Vasella, Bern

Electroencephalography
G. Scollo-Lavizzari, Basel

Evoked Potentials

Ophthalme-Neurology O Meienbers Bast

Ophthalmo-Neurology . Meienberg,
Neuropsychology
Th. Landis, Zurich W. Hartje, Aachen

Contents Vol.25,1986

No. 1 Sensory Action Potentials and Biopsy of the Sural Nerve in the Neuropathy of Nonmalignant $\operatorname{IgM}^{\wedge}$ Plasma Cell Dyscrasia 
Bogousslavsky, J.; Regli,

Concentrations of Glycine and Serine in Cerebrospinal Fluid during Disturbed Consciousness; a Study of the Therapeutic Effect of Thyrotropin-Rclcasing Hormone on the Consciousness Level Yanai, Y.; Shibasaki, T.; Kohno, N.; Mitsui, T.; Nakajima, H

Diagnostic Value of Spontaneous Afternoon Sleep in Epilepsy: Polysomnography Study of

96 Epileptic Patients

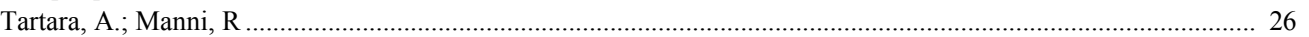

Pizotifen (Sanomigran) in Childhood Migraine. A Double-Blind Controlled Trial

Gillies, D.; Sills, M.; Fosythe, 1.

Long-Term Prognosis after Carotid Endarterectomy

Sacquegna, T.; D’Addato, M.; Baldrati, A.; Cortclli, P.; Lamieri, C; Merlo Pich, E.;

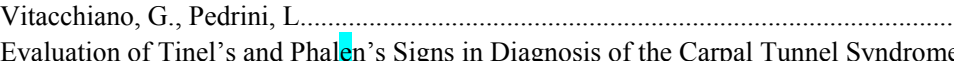

Evaluation of Tinel's and Phalen's Signs in Diagnosis of the Carpal Tunnel Syndrome
Heller, L.; Ring, H.; Costeff. H.; Solzi, P .............

Regional Cerebral Blood Flow during Interictal State: Differences between Temporal Lobe

Regional Cerebral Blood Flow during Interictepsy and Primary Generalized Epilepsy

Touchon, J.; Valmier, J.; Balddy-Moulinier, M.; Cadilhac, ,

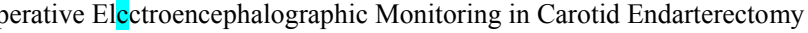

Spin Label Study of Red Blood Cell Membranes in Huntington's Disease

Kraus, P.H.; Vigenschowl H.; Przuntek, H....

Evoked Potentials in Multiple Sclerosis before and after High-Dose Methylprednisolonc

Infusion

Smith, T.; Zeeberg, I.; Sjo, 0

Therapeutic Effect of Lisuride in Advanced Parkinson's Disease

Meneghetti, G.; Bracco, F.; Giometto, B.; Ferla, S.: Schergna, E

No. 2 Preliminary Clinical Experience with Imipramine $\mathrm{HC} 1$ in the Treatment of Sleep Apnea Syndrome

Rubin, A-H.E.; Allroy! G.G.: Peled, R.; Lavie, P...

Efficacy of Pergolide and Mesulergine



Computed Tomography in CNS Tuberculosis

Trautmann, M.; Kluge. W.; Otto, H.-S.; Loddenkempcr, R........................................................................... 91

indifference Amnesique' in a Case of Global Amnesia following Acute Brain Hypoxia

Delia Sala, S.; Spinnler, H

Cerebrospinal Fluid Alterations in Bacterial Meningitis

Maida, E. Horvatits, E....

Pseudotumour cerebri: Incidence and Pattern in North-Eastern Libya

Radhakrishnan, K.; Sridharan, R.; Ashok, P.P.; Mousa, M.E ……………….......................................117

Benign Intra- and Extracranial Meningioma

Aeschlimann, A.; Mall, T.; Radii, E.; Gratzl, 0 ....................................................................................... 125

Muscle Strength Testing in Parkinson's Disease

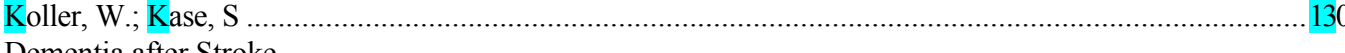

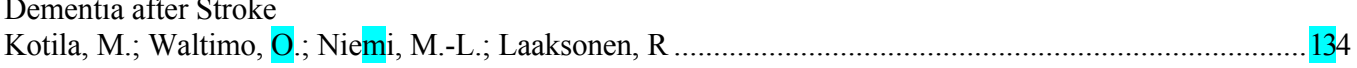

Kotila, M.; Waltimo, O.; Niemi, M.-L., Laksoner

Response of Cerebrospinal Fluid Pressure to Increase in Arterial Carbon Dioxide

Tension

Strecker, E.-P.; Novak, G.R.; Kauffmann, G.; Hemmer, R.; James, A.E., Jr..

Progressive Dystonia and Paraparesis in Cerebral Palsy

(148)

Movement Disorders Associated with Chronic GM2 Gangliosidosis. Case Report and Review of the Literature

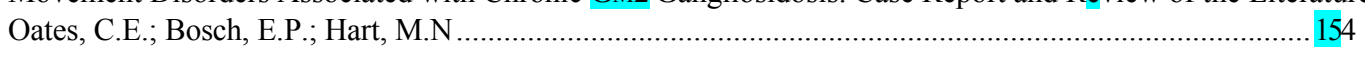

Announcement

No. 3 Secondary Cerebral Amebiasis due to Infection with Entamoeba histolytica. A Case Report with Computer Tomographic Findings

Schmutzhard, E.; Mayr, U.; Rumpl, E.; Prugger, M.; Pohl, P

Electrophysiological Study of the Snout Reflex in Normal Subjects and in Parkinsonian and

Pseudobulbar Patients

Girlanda, P.; Roberto, M.L.; Dattola, R.; Morgante, L.; Venuto, C; Messina, C. ... 166 Periventricular Metastases of a Primary Intracranial a-Fetoprotein-Producing Germ Cell Tumor

Bruyland, M.; Peters, O.; Schallier, D.; De Smedt, E.; Goossens, A.; Chabeau, A.;

Ebinger, G....

Immunoglobulins, Complement Components and Lymphocyte Subpopulations in Bell's

Immuns

Pedeler, C.A.; Matre, R.; Nyland, H.; Moller, P.. 
Kennedy Disease in an Italian Kindre

Guidetti, D.; Motti, L.; Marcello, N.; Vescovini, E.; Marbini, A.; Dotti, C; Lucci, B.;

Solime, F

Diagnostic Problems in Multiple Sclerosis. Two Cases with Clinical Diagnosis of MS Showing only a Diffusely Growing Malignant Astrocytoma

Roytta, M.; Latvala, M

197

Unilateral Asterixis: Case Report and Comments

Wee, A.S

Pathogenesis of Experimental Thyrotoxic Myopathy

Long-Term Lymphocytapheresis Therapy in Multiple Sclerosis. Preliminary Observations

Maida, E.; Hocker, P.; Mann, E............................................................................................................. 225

Partial Disconnection Syndrome following Penetrating Stab Wound of the Brain

Abe, T.; Nakamura, N.; Sugishita, M.; Kato, Y.; İwata, M..

Announcements

No. 4 Neurological Prognosis of High-Risk Preterm Infants with Peri-Intraventricular Hemor

rhage and Ventricular Dilatation

Amato, M.; Howald, H.; Muralt, G. vo

Transient Cerebral Ischemic Attack Caused by Hymenoptera Stings: The Brain as an Ana

phylactic Shock Organ

Meszaros, 1 ......

Myoglobin RIA in Detecting Carriers of Duchenne's Muscular Dystrophy

Sabria-Leal, M.; Gimeno-Leal, J.M.; Paret-Masana, A.; Rey-Joly Barroso, C.

Cryptococcal Meningoencephalitis. Case Report and Review of Italian Literature

Bussone, G.; La Mantia, L.; Parati, E.A.; Frediani, F.; Lamperti, E.; Boiardi, A.;

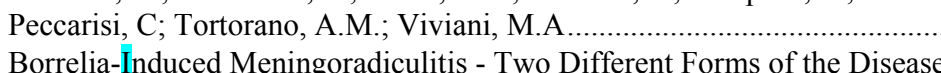

Kloter, I.; Adam, T.; Schabet, M.; Wietholter, H.; Peiffer, J

Experimental Neuropathy Induced by Methyl Mercury Compounds: Autoradiographic Study of GABA Uptake by Dorsal Root Ganglia Kumamoto, T.; Fukuhara, N.; Miyatake, T.; Araki, K..; Takahashi, Y.; Araki, S. ... 269

Complete Bilateral Relapsing Ophthalmoplegia in a Diabetic Patient with a Sensory-Motor

Distal Polyneuropathy

Cammarata, S.; Schenone, A.; Pasquali, G.F.; Tabaton, M

Does Prolonged Use of Diphenylhydantoin Predispose to Pulmonary Sarcoidosis?

Rubinstein, I.; Baum, G.L.; Hiss, Y.; Goldhammer, Y

Isoelectric Focusing and Two-Dimensional Gel Electrophoresis in Plasma and Cerebrospi

nal Fluid from Patients with Dementia

Alafuzoff, I.; Adolfsson, R.; Bucht, G.; Jellum, E.; Mehta, P.D.; Winblad, B ............................................... 285

Recurrent Transient Ischemic Episodes after Anticoagulation or Bypass Operation. Hemo

dynamic or Embolic Mechanism

Tsuda, Y.; Kimura, K..; Yoneda, S.; Hayakawa, T.; Etani, H.; Kamada, T................................................ 290

Neuropsychological Findings in Epileptic Amnesic Attacks

Gallassi, R.; Pazzaglia, P.; Lorusso, S.; Morreale, A

Measurement of Knee Tendon Reflex Latencies in Lumbar Radicular Syndromes

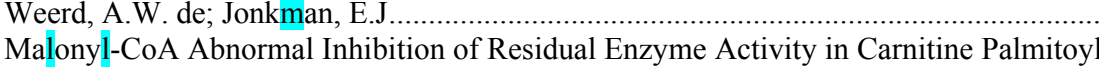

transferase Deficiency

Trevisan, C.P.; Angelini, C; Fiorellini, L.A.; İsaya, G.; Zacchello, G

No. 5 Viral Etiology in Myasthenia gravis? Analysis of Thymic Tissue

Smith, CLE.; Sydow, M. von; Hammarstrom, L

CSF Cytology of a Patient with Conversion of an Acute Lymphatic Leukemia to an Acute Eosinophilic Leukemia

Kollegger, H.; Preis, P.; Maida, E.; Zielinski, C.C.; Linkesch. W.; Bcttelheim, P.;

Aiginger, $\mathrm{P}$

Contents 
5-Hydroxytryptophan versus Methysergide in the Prophylaxis of Migraine. Randomized Clinical Trial

Titus, F.; Davalos, A.; Alom, J.; Codina, A

Value of Blood Coagulation Tests in Ischemic Cerebral Disease

Noren, I.; Garde, A

Prognostic and Electroclinical Features of Grand Mai Epilepsies

D’Alessandro, R.; Pazzaglia, P.; Tinuper, P.; Ferrara, R.; Fabbri, R.; Lugaresi, E. . . 340 Apolipoprotcins AI, All and HDL Phospholipids but not APO-B Are Risk Indicators for Occlusive Cerebrovascular Disease

Kostner, G.M.; Marth, E.; Pfeiffer, K.P.; Wege, H

erum Noradrenaline Response to Standing Up in Patients with Parkinson's Diseases

356

Turkka, J.T.; Juujarvi, K.K.; Lapinlampi, T.O.; Myllyla, V.V

Acid Phosphatase Activity of Cerebrospinal Fluid Cells in Bacterial and Abacterial Meningitis

De Reuck, J.L.; De Coster, W J.P. Eecken, H.M. vander....

Conjugate Pendular Nystagmus Evoked by Accommodative Vergence

Hara, T.; Kawazawa, S.; Abe, Y.; Hiyoshi, M.; Mizuki, Y.; Yamada, M ...................................................... 370

Influences on Blink Reflex Induced by IA Afferents in Human Subjects

Raffaele, R.; Emery, P.; Palmeri, A.; Perciavalle, V

New Neuromuscular Symptoms in Patients with Old Poliomyelitis: A Three-Year Follow-

Up Study



Two Autopsy Cases with Ruptured Dissecting Aneurysm of the Intracranial Vertebral

Artery

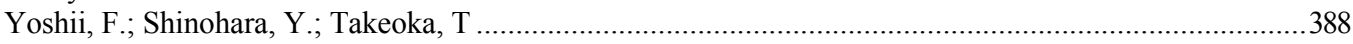

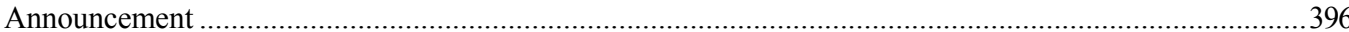

No. 6 Systemic Lupus Erythematosus Presenting with Recurrent Acute Demyelimating Polyneuropathy Millette, T.J.; Subramony, S.H.; Wee, A.S.; Harisdangkul, V...

Diagnosis and Treatment of Meningeal Carcinomatosis in Ten Patients with Breast Cancer

Schabet, M.; KJoeter, I.; Adam, T.; Heidemann, E.; Wietholter, H ............................................ 403

Choreoathetosis as Toxic Effect of Lithium Treatment

Walevski, A.; Radwan, M........................................................................................................... 412

Motor Neuropathy with Proximal Multifocal Persistent Conduction Block, Fasciculations

and Myokymia. Evolution to Tetraplegia

Roth, G.; Rohr, J.; Magistris, M.R.; Ochsner, F.

Styrcne-Induced Peripheral Neuropathy. A Case Report

Behari, M.; Choudhary, C; Roy, S.; Maheshwari, M.C

Correlations between Cerebral Grey Matter Flow and Hepatic Histology in Alcoholism

Valmier, J.; Touchon, J.; Zanca, M.; Fauchere, V.; Bories, P.; Balldy-Moulinier, M. . 428 Evaluation of Drug Therapy and Teratogenic Risk in a Rhone-Alpes District Population of Pregnant Epileptic Women

Robert, E.; Lofkvist, E.; Mauguiere, F.; Robert, J.M

Hypokalemic Myopathy Associated with Radiation Enteropathy

Murai, K.; Tsuruta, K.; Yamamura, Y.; Kuribayashi, T.; Kurihara, T.; Matsukura, S. 444 Efficacy of DSIIPP to Normalize Sleep in Middle-Aged and Elderly Chronic Insomniacs Schneider-Helmert, D

Contents

Optokinetic Nystagmus in Patients with Defects of the Central Visual Field

Crevits, L.; Vliet, A.G.M. van

Endodermal Sinus Tumor of the Pineal Region Presenting with a Radicular Pain

Meningeal Involvement as the Initial Symptom of B Cell Chronic Lymphocytic Leukemia

Boogerd, $\mathrm{W}$; Vroom, TM

Boogerd, W.; Vroom, T.M .

....461

Author Index........

Suppl. 1 Pharmacological Aspects and Neurological Potentials of Calcium Entry Blockers

Symposium at the Xlllth World Congress of Neurology, Hamburg, September 3,1985 Hartmann, A.; van Zwieten, P.A.

Suppl. 2 Sleep and Sleep Disorders

Symposium organized by the South-East European Society for Neurology and Psychiatry, Baden/Vienna (Austria), April 19-20, 1985 Lechner, H.; Korner, E. 
S. Kargcr Medical and Scientific Publishers

Basel $\bullet$ Munchen $\bullet$ Paris $\bullet$ London $\bullet$ New $\mid$ York $\bullet$ New Delhi $\bullet$ Singapore Tokyo $\bullet$ Sydney

Drug Dosage

The authors and the publisher have exerted every effort to ensure that drug selection and dosage set forth in this text are in accord with current recommendations and practice at the time of publication. However, in view of ongoing research, changes in government regulations, and the constant flow of information relating to drug therapy and drug reactions, the reader is urged to check the package insert for each drug for any change in indications and dosage and for added warnings
and precautions. This is particularly important when the recommended agent is a new and/or infrequently employed drug.

No part of this publication may be translated into other languages, reproduced or utilized in any form or by any means, electronic or mechanical, including photocopying, recording, microcopying, or by any information storage and retrieval system, without permission in writing from the publisher or, in the case of photocopying, direct payment of a specified fee to the Copyright Clearance Center (see 'Information for Readers and Subscribers').

C Copyright 1986 by

S. Karger AG, P.O. Box. CH-4009 Basel (Switzerland) Printed in Switzerland by Thiiir AG Offsctdruck, Pratteln 